\title{
Establishing authority in Spiritual Warfare literature
}

\section{Torsten Löfstedt}

Pentecostal and Charismatic Christianity is considered to be the most quickly growing form of Christianity in the world today. Pentecostals and Charismatic Christians belong to many different denominations and engage in a variety of practices but generally agree that the experiences of the working of the Holy Spirit that are described in the New Testament are available to Christians today. ${ }^{1}$ While it is the experience of the Holy Spirit that is of central importance to these Christians, some show considerable interest in a malevolent spirit world as well. A large number of books have been written by Pentecostal and Charismatic Christians regarding how to identify and defeat demonic forces. In one subgenre, known as Strategic Level Spiritual Warfare, authors claim to have received supernatural knowledge of spiritual forces that are in control of institutions, cities, and nations, and explain how to go about combating them. Several titles in this genre have become best sellers. In this article I identify strategies that some best-selling authors in this genre use to persuade their readers that their findings are reliable. While the authors in this tradition portray themselves as standing in opposition to the New Age movement, I note how they employ many of the same discursive strategies as New Age authors and others belonging to the Modern Esoteric Tradition (or Western Esotericism), as it has been described by Olav Hammer. ${ }^{2}$ By examining these parallels this article contributes to the history of religious ideas, Pentecostal studies and studies of American religion.

The Modern Esoteric Tradition is notoriously difficult to define; it is not an organized religion but includes various spiritual traditions that developed in the western world from about the age of the Enlightenment and were critical of organized Christian religion, incorporating traits from a variety of traditions distant from traditional Christianity. ${ }^{3}$ Examples of Modern esoteric traditions include Theosophy, Occultism and modern Paganism. ${ }^{4}$ The term 'New Age movement' refers to forms of Western Esotericism that

1 A. Anderson, An Introduction to Pentecostalism (Cambridge University Press, 2004) characterizes Pentecostalism as "a movement concerned primarily with the experience of the working of the Holy Spirit and the practice of spiritual gifts" (p. 14). The Pentecostal movement includes both classical Pentecostal denominations established in the early 1900's (such as the Assemblies of God), and Neo-Pentecostal or Charismatic congregations, that is congregations belonging to non-Pentecostal denominations that came to share the same interests in spiritual gifts. These flourished as a result of the Charismatic revival that spread through the USA in the 1960's (p. 144).

2 O. Hammer, Claiming Knowledge: Strategies of Epistemology from Theosophy to the New Age (Leiden: Brill, 2004).

3 See W. J. Hanegraaff, New Age Religion and Western Culture (Albany NY: SUNY Press, 1998) pp. $302-303$

4 Hanegraaff "Esotericism" in Hanegraaff, (ed.). Dictionary of Gnosis and Western Esotericism. (Leiden: Brill, 2005) p. 340, lists four characteristics that are intrinsic to western esotericism and two characteristics that are often but not always present in these traditions: (1) a belief in invisible and non-causal 'correspondences' between all visible and invisible dimensions of the cosmos, (2) a perception of nature as permeated and animated by a divine presence or life-force, (3) a concentration on the religious imagination 
developed after World War II, especially in the late 1960s and thereafter. In the view of Pentecostal and Charismatic authors whose works I study here, New Age is a form of demon worship. ${ }^{5}$ That of course is not how adherents of New Age movements would see themselves; they are more likely to characterize themselves as spiritual seekers.

The term 'spiritual warfare' is used by Christian authors in different ways. J.K. Beilby and P.R. Eddy identify four views of spiritual warfare, which they refer to as "the world systems model, the classical model, the ground-level deliverance model and the strategic level deliverance model." ${ }^{6}$ Authors working in the classical model of spiritual warfare may hold that personal demonic beings exist, but they do not encourage speculation about their actions or nature, and "reject the idea that Christians can be personally demonized". ${ }^{7}$ These authors affirm that Satan is real, but they argue that it is primarily in the moral arena that Christians must fight him; spiritual warfare "is a pastoral, theological term for describing the moral conflict of the Christian life." ${ }^{\prime 8}$ The spiritual forces that the believer must battle are forces of sin and temptation.

Authors who write of spiritual warfare from the viewpoint of the ground-level deliverance and strategic level deliverance models also address the need to withstand temptation and to be set free from bondage to sin but in addition they encourage the use of exorcism to free believers from various personal demonic beings. The strategic-level deliverance model differs from the ground level deliverance model in that in addition to affirming the necessity of delivering people who are demon possessed, its adherents teach that there exist demonic hierarchies in control of geographical territories that need to be identified and prayed against. Peter Wagner is the central figure in this form of deliverance ministries, which he refers to as Strategic-level Spiritual Warfare (SLSW). ${ }^{9}$

I do not aim to account for the development of the Deliverance movements as a whole, ${ }^{10}$ but have chosen to focus on the works of a few authors who have been especially influential and have made some particularly bold claims. From the early generation I look at works by

as a power that provides access to worlds and levels of reality intermediary between the material world and God, (4) the belief in a process of spiritual transmutation by which the inner man is regenerated and re-connected with the divine. Two non-intrinsic characteristics - frequently but not always present are (1) the belief in a fundamental concordance between several or all spiritual traditions, and (2) the idea of a more or less secret transmission of spiritual knowledge." This list is in turn a reworking of Faivre's influential definition of Western Esotericism.

5 See R. Holvast, Spiritual Mapping in the United States and Argentina, 1989-2005: A Geography of Fear. (Leiden: Brill, 2008), p. 33.

6 JK Beilby \& PR Eddy Understanding Spiritual Warfare: Four Views. (Grand Rapids: Baker Academic, 2012).

7 Beilby \& Eddy, Understanding Spiritual Warfare p. 35.

8 Powlison, David. “The Classical Model.” In Beilby \& Eddy (eds.), Understanding Spiritual Warfare, p. 92. I find it significant that in contrast to other spiritual warfare texts, Powlison's Power Encounters: Reclaiming Spiritual Warfare (Grand Rapids: Baker, 1995) has not been republished.

9 It is also referred to as Spiritual Mapping. See Holvast, Spiritual Mapping p. 4. I do not include Gregory Boyd in this direction, because although he mentions some SLSW authors in a footnote (God at War: The Bible and Spiritual Conflict (Downers Grove: InterVarsity Press 1997) p. 294), he does not build on them, nor does he mention SLSW or spiritual mapping. See further Holvast, Spiritual Mapping, p. 233.

10 J.M. Collins offers a historical survey of Deliverance literature, identifying several strains. I will focus on books and articles by authors he categorizes as belonging to the Charismatic deliverance movement. JM Collins. Exorcism and Deliverance Ministry in the Twentieth Century: An Analysis of the Practice and Theology of Exorcism in Modern Western Christianity (Paternoster, 2009). Collins's findings are summarized in his article "Deliverance and Exorcism in the Twentieth century", in Kay \& Parry, eds. Exorcism and Deliverance: Multidisciplinary Studies. (Paternoster, 2011) 
Derek Prince (1915-2003), Lester Sumrall (1913-1996); and Frank Hammond (1921-2005) \& Ida Mae Hammond (1925-1997); from the later generation Charles H. Kraft (1932-), Ed Murphy (1929-), C. Peter Wagner (1930-2016) and people belonging to Wagner's circle including Cindy Jacobs (1951-), George Otis, Jr. (1953-), and Becca Greenwood (1967-). These authors were all based in the USA. ${ }^{11}$ They belonged to various parts of the Pentecostal and Charismatic traditions, but their writings have not been commissioned by any denomination. ${ }^{12}$ Of these Peter Wagner is of special interest to me. Wagner was an unusually prolific writer and his ideas have had global reach. ${ }^{13} \mathrm{He}$ started out as a cessationist evangelical who believed that God only spoke to people through Scripture, but came to embrace the notion of extra-biblical revelation, of which he considered himself a recipient. ${ }^{14}$ Wagner served for thirty years as professor of Church Growth at Fuller Theological Seminary, an influential multi-denominational evangelical seminary in the USA where Charles Kraft also worked. As will be discussed below, this gave him a unique position of authority. ${ }^{15}$ Wagner also founded Global Harvest Ministries and the Wagner Leadership Institute, where he gathered around himself like-minded individuals who helped further propagate his ideas.

Many of the works studied here have been subjected to thorough criticism. ${ }^{16}$ Theologians have pointed out instances where the practices described by the abovementioned authors and other like them are based on implausible exegesis. ${ }^{17}$ Other scholars have noted how these works encourage a climate of fear. ${ }^{18}$ The Assemblies of God, an American Pentecostal denomination, has repeatedly warned its members about dangers with too great an interest in identifying demons, and have declared some spiritual warfare teachings to be unbiblical. ${ }^{19}$ But in spite of the substantial criticism these books continue to sell. Some of the works

11 Prince was born in India to British parents but moved to the USA in 1963.

12 Prince and Sumrall were ordained in the Assemblies of God, a Pentecostal denomination. Prince eventually left his pastorate, presumably because his belief that Christians could be demonized contradicted official AG doctrine (Collins, Exorcism p. 45). Collins considers Murphy an example of the convergence of Evangelical-Fundamentalist and Charismatic strains of spiritual warfare thought (Exorcism p. 192), and he considers Wagner to be a "significant departure" from the Charismatic deliverance movement (p. 101).

13 Wagner is said to have authored more than 70 books. (Wagner, Breaking Spiritual Strongholds (1993/2015, backcover).

14 Wagner, Spiritual Warfare Strategy, p. 52-53.

15 As will be discussed below, many of Wagner's colleagues at Fuller found his views quite controversial. 16 Several important studies of spiritual warfare literature have been written. The most important is Spiritual Mapping, a thorough study by Holvast, which examines the history, development, self-understanding and criticism of the SLSW movement. This work engages both literature advocating SLSW and works critical of it. Works not referred to by Holvast include the following: MSB Reid. Strategic Level Spiritual Warfare: A Modern Mythology? A detailed evaluation of the biblical theological and historical bases of spiritual warfare in contemporary thought. (Fairfax, VA: Xulon Press, 2002). This work covers similar material to Holvast, but he seems not to have been aware of it. Important studies written later than Holvast include S. McCloud, American Possessions: Fighting Demons in the Contemporary United States. (Oxford: Oxford University Press, 2015), who examines this literature in the context of contemporary American popular culture, and G.R. Smith, The Church Militant: Spiritual Warfare in the Anglican Charismatic Revival (Eugene, OR: Wipf \& Stock, 2016).

17 I give examples of criticism below.

18 See McCloud, American Possessions, p. 22. Van der Meer's doctoral thesis (2008) argues that applying SLSW to the cultural context of Malawi would be deleterious, reinforcing the fear of witchcraft.

19 See the AG official position paper "Can born-again believers be demon possessed?" (1972) and their paper "Spiritual Warfare: Attacks of Satan" (no date). https://ag.org/Beliefs/Topics-Index/Spiritual-WarfareAttacks-of-Satan 
studied here were first published in the 1970s and are still in print. The cover of the fiftieth printing of Pigs in the Parlor claims that more than one million copies have been printed since the first edition came out in $1973 .{ }^{20}$ While most works in this genre are quick reads, even heavier texts in this genre have sold well. Ed Murphy's The Handbook of Spiritual Warfare numbers 626 pages; its cover claims: "over 100,000 copies sold." 21 Several of these authors, including Prince, Sumrall, and Kraft, traveled widely. Works by Kraft, Prince, Sumrall, and Wagner have been translated into other languages and have had an impact far beyond the English-speaking world. In his thorough study of the SLSW genre Holvast notes, "there is virtually no country in the world where Spiritual Mapping has not been practiced."22

In the pages that follow I identify discursive strategies these bestselling authors use to establish authority. I show that they try to make their assertions plausible by anchoring them in Biblical texts, as do other Evangelical authors, ${ }^{23}$ but unlike many of their co-religionists they also employ discursive strategies that they share with authors in the Modern Esoteric Tradition: they construct tradition largely by appealing to experience (their own experiences, experiences of other SLSW authors, and the spiritual experiences of non-western peoples) rather than by appealing to established scholarship, and they use language that sounds scientific while neglecting scientific method. ${ }^{24}$ They model for their readers a trusting attitude and discourage them from questioning by limiting the number and kind of references to other literature they make.

\section{Some central teachings in the Spiritual Warfare tradition}

Central to SLSW is the notion of territorial spirits, "powerful, high-ranking spirit beings that have authority over particular geographic regions of the earth." ${ }^{25}$ SLSW authors teach that these territorial spirits are a hindrance to spreading the Gospel, but they can be defeated through warfare prayer. To defeat the demons, it helps if one can identify them by name, which is something that may be accomplished with the aid of 'spiritual mapping'. Wagner \& Greenwood offer the following summary of this practice:

Spiritual mapping is the practice of identifying the spiritual conditions at work in a given community, city, or nation. By gathering objective information (including key historical facts such as foundational history, locations of bloodshed, idolatrous practices, key historical leaders, broken covenants, and sexual immorality) and combining it with spiritual impressions (prophecy, revelation, words of knowledge, dreams, and visions), believers can prayerfully

20 F. Hammond \& I. Hammond. Pigs in the Parlor: The Practical Guide to Deliverance. (Kirkwood, MO: Impact Christian Books, [1973] 2014).

21 E. Murphy. The Handbook for Spiritual Warfare. Revised and updated. (Nashville: Thomas Nelson, 2003).

22 Holvast, Spiritual Mapping p. 3.

23 Gary Dorrien (The Remaking of Evangelical Theology, Louisville, KY 1998) defines Evangelicalism as: "a Christian movement that emphasizes the Reformation doctrine of the final authority of scripture, the real historical character of God's saving work recorded in scripture, salvation to eternal life based on Christ's redeeming death and resurrection, the importance of evangelism and missions, and the importance of a spiritually transformed life." Pentecostals are generally considered to be Evangelical, but not all Evangelicals share the Pentecostal and Charismatic emphasis on experiencing the Holy Spirit.

24 Compare the three major discursive strategies used in the Modern Esoteric Tradition according to Hammer (Claiming Knowledge p. 23): "scientism, the construction of tradition and the appeal to experience."

25 Beilby \& Eddy, Understanding Spiritual Warfare p. 41. 
combine all of this information and draw a map that identifies the open doors between the spirit world and the material world. ${ }^{26}$

By reading up on the history of an area and by receiving wisdom from God, one can identify the powers that rule over an area.

In her guide to Strategic-level spiritual warfare, Rebecca Greenwood gives a list of "root bondages that have powerful effects on a land and its people." ${ }^{27}$ It includes War, Trauma, Land violations, Covenants made with darkness, and Freemasonry strongholds. ${ }^{28}$ Greenwood also shares with her readers some inside information on the identity of some key demons; one of them is none other than the Queen of Heaven, a term well-known in Roman Catholic circles as a title given the Virgin Mary, but is now revealed to be an evil power:

The Queen of Heaven is a major demonic personality responsible for hatred toward Jewish people and non-acceptance of any denominations that do not focus their worship toward her and the many forms in which she appears. I believe that this adversarial demonic force played a decisive role in the Holocaust. ${ }^{29}$

To many Christians these claims would seem quite new. SLSW authors claimed however that their belief in territorial demons was supported both by experience and by Scripture.

\section{Construction of Tradition: Selective reading of scripture}

While writers in the SLSW warn of the dangers of New Age teachings, they resemble the New Age movement in being critical of mainstream Christianity and Enlightenment thought. $^{30}$ They criticize both Roman Catholicism, which they claim involves demon worship, and mainline Protestant denominations, which do not recognize the reality of the spirit world, and instead construct a new Christian tradition pulling from a variety of sources.

In true Protestant tradition, Kraft, Murphy, Wagner and other SLSW authors seek to support their views in Scripture. Unlike Modern Esoteric authors, SLSW authors have to anchor their teaching in the Bible, which they maintain is the ultimate authority. ${ }^{31}$ But they differ from other contemporary interpreters in seeking to interpret it without being blinded by the values of the Enlightenment. ${ }^{32}$ These authors note that while the Gospels make frequent reference to the devil, demons and exorcism, mainline theologians generally gave these topics short shrift compared to other topics of theology, perhaps because these texts reflected a

26 Wagner \& Greenwood, "Strategic-level” pp. 182-183.

27 Greenwood, Authority to Tread p. 93. On root bondages, see Otis “Overview” pp. 46-47.

28 Greenwood, Authority to Tread pp. 93-94.

29 Greenwood, Authority to Tread p. 49. The notion that the Queen of Heaven is a demonic spirit is widely accepted in these circles. Cf. C. Jacobs. "Dealing with Strongholds" in C.P. Wagner (ed.), Breaking Spiritual Strongholds in Your City, (2015), pp 74-75; Lorenzo, Victor. "Evangelizing a City Dedicated to Darkness" in C.P. Wagner (ed.), Breaking Spiritual Strongholds in Your City, [1993] 2015, p. 167 (who credits Jacobs). Peter Wagner has authored a book on the Queen of Heaven (Confronting the Queen of Heaven, 1998, revised ed. 2001).

30 Hanegraaff, New Age Religion p. 302, characterized New Age thinking as a "reaction to the ideas and values which are perceived as having dominated western culture during the past two thousand years."

31 Cf. Wagner, Spiritual Warfare Strategy, p. 53: "The Bible remains the only final and authoritative litmus test for divine revelation."

32 Wagner, Spiritual Warfare Strategy, p. 74-75. 
worldview too different from their own. ${ }^{33}$ Liberal theologians have tended to demythologize forces of evil in the Bible, rather than considering them to be personal beings. ${ }^{34}$ Several authors in the spiritual warfare field relate how they had taken these demythologized interpretations for granted until they were confronted with people in the mission field for whom demons were reality. ${ }^{35}$ These encounters caused them to turn to scripture again to see what it actually says about demons. They found that the worldview of biblical authors is much closer to that of 'animist' cultures they had met with on the mission field than to the worldview of Western mainline churches, and they suggest that the New Testament message can hardly be separated from that worldview. ${ }^{36}$ Furthermore, the authors claim that the way that New Testament authors viewed the world corresponds better to reality than the worldview colored by the western Enlightenment. SLSW authors claim that there exists an invisible spirit world that animists today are still aware of, and that impacts people today whether they believe in its existence or not. They then proceed to interpret the Bible in light of this assumption and find numerous hitherto neglected references to demons and spirit beings there. They also interpret their own experiences in light of the existence of such beings. $^{37}$

SLSW authors find support for their unique teaching about territorial demons in about a dozen Biblical texts, including: Daniel 10; Deut 32:8-9 (as it reads in the Septuagint); Psalm 82:1-8; Mark 5:1-20 \& parallels (the Gerasene demoniac); Luke 11:14-26 \& parallels (the Beelzebul pericope); Acts 8:9-13 (Simon Magus), Acts 13:6-12 (Bar-Jesus the sorcerer), Acts 16:16-18 (the python spirit); Acts 19:23-41 (Artemis of the Ephesians) and Eph 6:10-17. Of these, the most important text for SLSW authors is Daniel 10. I will look at how this text has been interpreted in the SLSW tradition. ${ }^{38}$ Frank Hammond offers the following summary and interpretation of Daniel 10:

Daniel was seeking a word from God through prayer and fasting. After three weeks an angel appeared. The angel explained that he has been delayed in getting to Daniel with God's message by an encounter with 'the prince of the kingdom of Persia.' He does not refer to an earthly prince, for no mere man could withstand a heavenly messenger. He is speaking of a

33 In a review article on studies about the devil in the field of Biblical studies, DR Brown, "The Devil in the Details" Currents in Biblical Research 9 (2011), pp. 200-201 argues that "Modern scepticism of the supernatural ... led to a general distrust in, or at least a failure to engage seriously with, Satan as an acceptable academic topic."

34 The classical expression of this view is that of Rudolf Bultmann, who claimed it was impossible for modern man to believe in demons (See "New Testament and Mythology" in R. Bultmann, et als., Kerygma and Myth: A Theological Debate. New York: Harper \& Row, 1961.)

35 Murphy, Handbook, xiii. Kraft (Defeating Dark Angels, pp. 12-13) relates that he came to recognize the reality of demons when he taught a class on Signs and Wonders at Fuller.

36 Cf. Wagner \& Greenwood, "Strategic-level", p. 126. They have a point. Whereas mainline theologians have previously argued that belief in spirits was part of the cultural background of the early Church but not a core part of the Christian message, several scholars have recently stressed that Jesus' authority over unclean spirits is given central importance in the Synoptic Gospels See Davies, Jesus the Healer, Twelftree, In the Name of Jesus, and Witmer, Jesus, the Galilean Exorcist.

37 Collins, Exorcism, p. 192.

38 Space will not allow for a proper exegetical study of this passage here. For an exemplary study on Daniel 10 and its implications for spiritual warfare, see T. Meadowcroft, "Who are the Princes of Persia and Greece (Daniel 10): Pointers towards the Danielic Vision of Earth and Heaven. JSOT 29 (2004): 99-113. 
demon prince. From this it is clear that there are ruling demon spirits placed by Satan over nations and cities in order to carry out his evil purposes. ${ }^{39}$

Wagner briefly discusses this passage: "The Bible teaches that the things we today call 'territorial spirts' do exist." ${ }^{40}$ Like Hammond he refers to the prince of Persia and the prince of Greece, and argues simply: "these are, quite evidently, seen as 'ontological' [sic] realities, powerful enough in the invisible world to have delayed Michael, an angel sent by God Himself to deliver an answer to prayer to Daniel, for no less than 21 days." 41 Wagner does not cite Hammond's interpretation, but he refers to a commentary on Hebrews by the respected New Testament scholar FF Bruce, which ties this passage together with that other classic text in SLSW circles, Eph 6:12. Wagner does not offer arguments against alternative interpretations, nor does he explain what he means by 'ontological' or why he put the word in quotes. ${ }^{42}$ As others have noted, alternative explanations are generally not given in SLSW literature; their interpretation is presented as the only reasonable one. Otis (who coined the term 'spiritual mapping') offers the following interpretation of Daniel 10 with a very brief supporting argument:

Here we have a well-defined case of an evil spiritual being ruling over an area with explicitly proscribed boundaries. Even non-scholars must regard it as significant that this creature is not referred to as the prince of China or the prince of Egypt. ${ }^{43}$

That is not much of a defense of what is a rather controversial interpretation of the passage in question. $^{44}$

\section{Scientism and the Ambivalent Relationship to Scholarship}

SLSW authors have an ambivalent relationship toward scholarship. They refer to Biblical scholars and others who support their views, but they question the validity of the basic assumptions of contemporary Biblical scholarship and rarely seek to answer their critics. Not being established theologians, and coming up with new interpretations of Biblical texts that in some cases seemed quite strained, they were swiftly criticized by Biblical scholars for not doing proper exegesis. ${ }^{45}$ For example, one critic of SLSW notes that Daniel does not learn

39 Hammond \& Hammond, Pigs in the Parlor p. 14. Hammond has also written The Saints at War: Spiritual Warfare over Territories (Kirkwood, MO: Impact Christian Books, 1986) which develops these views.

40 Wagner, Spiritual Warfare Strategy, 167.

41 Wagner, Spiritual Warfare Strategy, 168

42 Wagner, Spiritual Warfare Strategy, 168/288 and "Territorial Spirits" p. 316. Bruce in turn builds on Caird's Principalities and Powers (1956. ix, 81 etc.). In the revised edition of the Hebrews commentary (1990), Bruce discusses this passage on p. 72 (re. Heb. 2:5).

43 Otis, "Overview" p. 38.

44 Other SLSW authors who refer to this passage are B. Beckett. "Practical Steps toward Community Deliverance" in C.P. Wagner (ed.), Breaking Spiritual Strongholds in Your City, (2015), p. 144 \& Caballeros, "Defeating the Enemy" p. 129.

45 E.g. J. Hart. “The Gospel and Spiritual Warfare.” Journal of the Grace Theological Society 10 (1997): 19-39; Carson, "God the Bible, and Spiritual Warfare." Clinton Arnold, who has also published in spiritual warfare circles (e.g., C.E. Arnold. Three Crucial Questions about Spiritual Warfare. Grand Rapids: Baker, 1997), is a notable exception. His studies of folk belief in Colossians and Ephesians are solid contributions to biblical exegesis (C.E. Arnold. The Concept of Power in Ephesians. (Grand Rapids: Baker Book House, 1989); C.E. Arnold. The Colossian Syncretism: The Interface between Christianity and Folk Belief at Colossae (Grand Rapids: Baker Books, 1996). 
the names of the angels in charge of Persia and Greece, nor he does he pray against them. ${ }^{46}$ This author dates Daniel the same way Wagner does, but points out that Daniel's prayer did not have immediate effect; "the prince of Persia continued to exert his influence for another two hundred years until the time of the Greek Empire." ${ }^{47}$ Clinton Arnold (a Biblical scholar who was sympathetic to SLSW while standing somewhat apart from the movement) noted that while Daniel 10 and two other Old Testament passages may refer to evil spiritual beings, there is no suggestion that these beings are bounded by geographical borders. ${ }^{48}$ The way that SLSW authors handle the Bible has been criticized on many other counts as well. For example, they do not discuss the genre to which the passage in Daniel belongs (apocalyptic), nor do they discuss arguments for a later dating of Daniel and the implications that would have for their interpretations, but treat these texts as though they were objectively reported glimpses into heavenly realities dating to the Babylonian exile. ${ }^{49}$ SLSW authors have generally ignored the criticism of their exegesis and have continued republishing their works and composing new texts based on the same premises.

The way SLSW authors handle Biblical texts such as Daniel 10 may be compared to the phenomenon of "source amnesia", which according to Hammer is typical of much Modern Esoteric literature. This is "the propensity to gloss over or be unaware of the fact that processes of reinterpretation have taken place." ${ }^{50}$ Hammer continues,

Each major spokesman will regard the more or less radical reinterpretations of his or her predecessors as a self-evident point of departure. With time, a chain of transmission is built up, in which the latest spokespersons may have a horizon in time that stretches no more than twenty or thirty years back, and in which anything older than this is considered to belong to a diffuse, ancient past. ${ }^{51}$

Wagner's followers in spiritual warfare circles repeat his interpretations, which in turn follow in the same tradition as the Hammonds and Sumrall. No serious attempts are made at showing why alternative interpretations do not hold. The readers are led to believe that the interpretations put forward by SLSW authors are the only reasonable ones.

On occasion Wagner does try to defend his controversial teaching, but these defenses verge on ad hominem attacks rather than being scholarly exchanges. Wagner, who together with Kraft belonged to the School of World Mission at Fuller Theological Seminary, recounts how his teaching on spiritual warfare had been heavily criticized by his Fuller colleagues in the School of Theology. ${ }^{52}$ In defending himself against his colleagues Wagner wrote,

46 Stevens, "Daniel 10", p. 430.

47 Stevens, "Daniel 10", p. 430.

48 Arnold, Three Crucial Questions, p. 151.

49 Unlike mainline scholars who argue that large parts of the Book of Daniel, including chapters 8-12, were written in the Maccabean period (see Collins 1993.38), Arnold (Three Crucial Questions, p 154) accepts the dating of Daniel given in the biblical texts: "Daniel received his vision during the third year of the reign of Cyrus, king of Persia, in 535 B.C." See also S. Page, Powers of Evil, 64: "The portrayal of the princes of the nations in Daniel reveals that the unfolding of human history is not determined solely by the decisions made by human beings, for there is an unseen dimension of reality that must also be taken into account."

50 Hammer, Claiming Knowledge, p. 180.

51 Hammer, Claiming Knowledge pp. 180-181.

52 Wagner \& Greenwood, "Strategic-level”, pp. 175-176. 
It seems to me that the most fundamental issue we have before us relates to research methodology. Much of our failure to hear each other stems from this. What is the relationship between theology and experience? Between the exegetical and the phenomenological? Between philosophy and social science? ... Between library research and field research?... Between Western worldviews and Third World worldviews? ${ }^{53}$

Wagner classified himself as a social scientist, someone whose conclusions are based on experience and field research. His colleagues in the School of Theology had in his view uncritically adopted the reductionist premises of the Enlightenment. ${ }^{54}$ Their largely secular worldview and their isolation from the world outside of academia kept them from realizing the reality of the spirit world and caused them to misinterpret Scripture. ${ }^{55}$ Significantly, however, Holvast notes that Wagner and his SLSW colleagues were roundly criticized not only by theologians but also by anthropologists and other social scientists for their lack of methodological rigor, their confusion of phenomenological description with ontological reality and their tendentious interpretations of the material. ${ }^{56}$

Although he defends himself by appealing to his scholarly credentials, Wagner also argues that he doesn't need scientific proof for his claims. As is discussed below, Wagner and other spiritual warfare authors put great weight on their own experiences. Wagner says, "some parts of reality are primarily spiritually discerned, and therefore do not lend themselves to scientific analysis;" indeed, "no scientific evidence can be cited that proves any reality [sic!] that the Holy Spirit exists". ${ }^{57}$ In another article he makes the following distinction between anthropology and spiritual mapping: "Anthropology sees culture as it appears to be, while spiritual mapping attempts to see culture as it really is." ${ }^{, 58}$ Wagner assumes the identity of an anthropologist to defend himself against those who criticize his scholarship, but it is not something that generally colors his research.

Hammer describes a similar ambivalent attitude toward science and scientific terminology in the Modern Esoteric tradition, and labels it scientism:

Scientism is the active positioning of one's own claims in relation to the manifestations of any academic scientific discipline, including, but not limited to, the use of technical devices, scientific terminology, mathematical calculations, theories, references and stylistic features without, however, the use of methods generally approved within the scientific community, and without subsequent social acceptance of these manifestations by the mainstream of the scientific community through e.g. peer reviewed publications in academic journals. ${ }^{59}$

A closer look at SLSW literature gives more examples of this ambivalent attitude toward science. Holvast notes that SLSW authors rarely engage carefully with the works that they cite, they refer to them only in so far as they support their claims. ${ }^{60}$ In Spiritual Warfare

53 Wagner \& Greenwood, "Strategic-level”, p. 176.

54 Wagner, Spiritual Warfare Strategy p. 74. Other authors share in this criticism of the enlightenment or postenlightenment paradigm. Boyd, God at War, p. 11, criticizes the "post-Enlightenment naturalistic worldview".

55 Compare Murphy (Handbook p. xiii): "In the wake of the eighteenth-century rise of rationalism known as the Enlightenment, Western theology lost an intuitive, historic understanding of the spirit world."

56 See Holvast, Spiritual Mapping, pp. 260-271.

57 Wagner, Spiritual Warfare Strategy p. 65.

58 Wagner, Breaking Spiritual Strongholds p. 58, his emphasis.

59 Hammer, Claiming Knowledge p. 206.

60 Holvast, Spiritual Mapping p. 176. 
Strategy, Wagner gives more references to scholarly literature than is typical for books of this genre. But he is not as careful as one would expect an academician to be. In this book, he makes a rather controversial claim that Beelzebub is not to be equated with Satan, but is a high-ranking demon in Satan's service. On what grounds does he reject the traditional interpretation? "The reason I have concluded he [Beelzebub] is a principality under the command of satan [sic] is that the consensus of written materials I have examined and of personal interviews I have conducted with experts about the occult lead me to that judgment." ${ }^{61}$ Here we would really like references to specific works and people, but he doesn't give any. Similarly, in Defeating Dark Angels, Kraft criticizes Christians who think demon possession is just another culture's name for psychological illness. He claims, "recent studies question the ability of psychological counseling to bring healing." 62 But he gives no references to these studies.

Curiously, SLSW authors don't even relate to earlier works by colleagues in the movement in a systematic way. They give the impression that as spiritual warfare practices were developing quickly and the Holy Spirit was constantly revealing new truths, there was no need to get bogged down with earlier research. Holvast explains, "The tendency was to go by [the movement's] most recent publications and consensus without necessarily comparing it to previous publications. ${ }^{63}$ Of course, in refraining from showing in what respects claims that were previously made within the movement are no longer held to be true, the authors also make it easier for their readers to accept what they write without question.

It is typical of the Spiritual Warfare literature studied here that the authors ignore criticism against their claims. In his dictionary article on spiritual warfare, Kraft only includes works that support his perspective, none that question its validity. ${ }^{64}$ In his anthology Supernatural Forces in Spiritual Warfare, Wagner actually includes responses to most of the papers included, but none of the responses gives any thoroughgoing criticism of the papers. ${ }^{65}$ Wagner claims the moral high ground in refusing to answer criticism from other Evangelicals; "We have no intention to make ourselves look good by making our brothers and sisters in Christ look bad, and you will find none of that in this book." ${ }^{66}$ In Spiritual Warfare Strategy he writes, "I welcome the sometimes energized discussions we have been experiencing about strategic-level spiritual warfare", but he doesn't explain on what points he had been criticized. ${ }^{67}$ Wagner comes across as fair and balanced, but his readers remain largely unaware of the many points on which he had been criticized; they are not given the opportunity to weigh the arguments to see which are more plausible. Wagner indeed claims he is acting in this respect on divine command: "since $1980 \mathrm{I}$ had received a clear directional mandate from God not to engage in any more polemics." ${ }^{\text {"6 }}$ Were he to answer his critics he would be going against the will of God. Whether God discourages scholarly debate or not, when SLSW authors ignore criticism raised against them, they can more easily persuade

61 Wagner, Spiritual Warfare Strategy pp. 143-144.

62 Kraft, Dark Angels p. 43.

63 Holvast, Spiritual Mapping p. 171.

64 Kraft, "Spiritual Warfare" p. 1096.

65 Wagner, Supernatural Forces.

66 Holvast, Spiritual Mapping p. 232 quoting Wagner, Breaking Strongholds in your City p. 19.

67 Wagner, Spiritual Warfare Strategy p. 33. He gives a brief summary on p. 34.

68 Wagner, Spiritual Warfare Strategy p. 35. See also Wagner, Breaking Spiritual Strongholds p. 24. 
readers without scholarly training that their views are firmly established. Significantly, authors of Modern Esoteric literature also tend to ignore criticism against their claims; this is part of their discursive strategy; Hammer writes, "many Esoteric texts show little or no overt awareness of the controversial nature of the claims they present, despite the ready availability of opposing views." 69

In short, although they at times use academic language, the attitude Wagner and much of the SLSW movement displayed was generally anti-academic. ${ }^{70}$ For evangelical readers distrustful of the findings of liberal theologians and critical Bible scholars, this might actually make the warfare authors more credible. The authors are sufficiently established as scholars to allow readers to suspend their disbelief, while standing clearly apart from the scholarly establishment that they have been taught to distrust.

\section{Construction of Tradition: Experiences read in the light of Non-Christian religions}

A key assumption lying behind SLSW literature is that there is a spiritual world of which most traditional Christians are unaware, but which other religious traditions recognize. Wagner suggests Christians should accept large parts of the spiritual worldview of nonChristians. He writes that non-Christians may have spiritual insights Christians could use: "some non-Christians who are deeply embedded with the demonic forces of darkness in the world today might possess valid information about the spirit world, which can be used to help spread the kingdom of God." ${ }^{71}$ He explains elsewhere, "the spirit world to which they are dedicated is a real world, not a figment of their 'heathen' imaginations. Therefore, some things about it can be accurately known."72 Murphy writes along the same lines, "Africans, Asians, Latin Americans, and the inhabitants of Oceania know intuitively the reality of the spirit world. They know invisible spirit beings both good and evil continually interact with human beings." 73 The attitude toward religious tradition that SLSW authors show here is similar to that of those writing in the Western Esoteric Tradition. Traditional Western theology is rejected, and the authors turn to distant peoples who they claim have a better understanding of things spiritual. ${ }^{74}$

While SLSW authors refer to scripture as a central authority and refer to belief systems of animists, their unique theology is arguably most clearly dependent on New Age beliefs. One might say that the SLSW movement piggybacks on an interest in the New Age. Typically, SLSW authors warn about the dangers of New Age, as does Dickason on the first page of his study of angels. ${ }^{75}$ But they also borrow ideas from New Age literature. Some SLSW authors recognize similarities between their thoughts and New Age ideas. Cindy Jacobs writes

69 Hammer, Claiming Knowledge p. 251.

70 Holvast, Spiritual Mapping p. 187; see also Reid, Strategic Level pp. 130-131. Collins (Exorcism, 192) describes Murphy's Handbook for Spiritual Warfare as a work that gives expression to a "militant antiEnlightenment spirituality."

71 Wagner \& Greenwood, "Strategic-level”, p. 127.

72 Wagner, Spiritual Warfare Strategy p. 67.

73 Murphy, Handbook p. xiv.

74 Hammer, Claiming Knowledge, p. 89.

75 Dickason, Angels, p. 9. Compare also Murphy, Handbook, p. xiv: “demons flow where Satanism, Satanic occult practices, and the New Age movement flourish." 
regarding the term spiritual mapping: "To be honest, I had some reservations about the term when I first heard it. It sounded a bit New Age to me."76 Greenwood likewise tries to persuade her Christian readers to engage in spiritual mapping, building explicitly on ideas borrowed from New Age circles. She claims that the identification of power points and ley lines is of central importance to successful spiritual mapping. The term 'ley lines' was coined by amateur archaeologist Alfred Watkins (1855-1935), who on the basis of photographs he had taken in Britain argued that significant archaeological features were found along straight lines, which he called ley lines. This notion was popularized by the English esoteric author John Michell in The View over Atlantis (1969) who connected it with notions of feng shui and filled it with spiritual significance. ${ }^{77}$ Greenwood builds on New Age interpretations of ley lines, but claims that these lines rather than conveying positive spiritual energy in fact serve to give Satan control over an area. She continues,

As the Body of Christ, we have the responsibility of breaking the power of these ley lines and claiming the land for the glory of God! Let's no longer allow the enemy to gain further control over our cities, regions and the nations. The 'energies' between power points need to be broken and the land gripped in darkness set free. ${ }^{78}$

Greenwood thus builds her Christian practice on a reinterpretation of New Age ideas. Wagner similarly grants that New Age gurus have reliable spiritual knowledge.

Certain people such as shamans, witch doctors, practitioners of Eastern religions, New Age gurus, or professors of the occult on university faculties are examples of the kind of people who may have more extensive knowledge of the spirit world than most Christians have. ${ }^{79}$

It is strategic for SLSW authors to affirm that at least some of the experiences that people in the New Age movement have reflect spiritual realities. Were they to reject all New Age claims on rationalistic grounds, those same rationalistic arguments could be turned against their own claims as well. ${ }^{80}$

Like New Age and other Esoteric authors, SLSW authors incorporate various kinds of modern folk religious material including urban legends and conspiracy theories into their scheme. ${ }^{81}$ Wagner for example latches on to the Bermuda triangle which he considers to be of spiritual significance, ${ }^{82}$ while Kraft and Murphy speak of "satanic ritual abuse," ${ }^{83}$ a popular theme among conspiracy theorists in the 1980s in America (most notably in the McMartin pre-school trial). ${ }^{84}$ McCloud notes that authors in the SLSW traditions have also latched on to the pop-cultural fascination with ghost stories, with the twist that they reveal the ghosts to in fact be demons. ${ }^{85}$

\footnotetext{
76 Jacobs, "Dealing with Strongholds" p. 76.

77 Holvast, Spiritual Mapping, p. 230.

78 Greenwood, Authority to Tread, p. 97.

79 Wagner, Spiritual Warfare Strategy, p. 143.

80 So also Collins, Exorcism, p. 125.

81 Hammer (Claiming Knowledge, p. 209) notes that the Esoteric Tradition "appropriates contemporary legends," stories relating to Atlantis, crop circles, and ancient astronauts, for example.

82 Wagner, Supernatural Forces in Spiritual Warfare, p. 84.

83 Kraft, Defeating Dark Angels, p. 61; Murphy, Handbook, p..xiv.

84 Collins, Exorcism, p. 142. notes, "The Occult Revival and enthusiastic Christianity enjoyed a perverse symbiotic enmity."

85 McCloud, American Possessions, pp. 38-39.
} 
SLSW authors create their tradition by combining material from New Age teachers, popular conspiracy theories, reports from the mission field and a handful of Bible passages that they interpret in their own way. No serious attempts at source criticism are made. ${ }^{86}$ This combination of material is presented as constituting a consistent whole, as a true picture of the spiritual realm. While the end result is not as creative as what is found in Modern Esoteric literature, it is clear that SLSW authors have also engaged in a non-historical construction of tradition.

Whereas one might have expected that claims that animists and New Age adherents have a better grasp of spiritual realities than Christian theologians would be difficult for their Christian readers to accept, Wagner and other SLSW authors support such claims in part as was noted by questioning the authority of traditional theological scholarship, but primarily by referring to their own experiences. I will look at their use of this discursive strategy next.

\section{Appeal to Experience}

Of the various discursive strategies used by SLSW authors studied here, the appeal to experience is most important; the other two (construction of tradition and scientism) follow from it. Their experiences are the lens through which they read scripture, and their experiences are what allow them to question the scholarly establishment. ${ }^{87}$ Derek Prince opens his book by referring to the first time he cast out a demon from a Christian; he tells this story in greater detail later on in the same book. ${ }^{88}$ Lester Sumrall begins his book by giving a long account of how he set a prisoner in Manila named Clarita free from a demons. ${ }^{89} \mathrm{Kraft}$ begins Defeating Dark Angels by quoting a thank you letter he had received from 'Karen', who had been delivered from a demon, and writes further on "Having worked with the Holy Spirit to bring deliverance to more than 2,000 Christians - and dealing with many thousands of demons in the process - I want to share with you what God has been teaching me. ${ }^{90}$ These authors establish their authority by appealing to their own success in deliverance ministries. They also portray their success in terms of their faithfulness to God's calling.

In Christian circles, God is the ultimate source of authority. Wagner bases his authority on divine calling. "While in Manila, the Lord spoke to me in a voice that, although not audible, was almost as clear as if it had been: 'I want you to take leadership in the area of territorial spirits." "91 In Breaking Spiritual Strongholds Wagner explains he had originally planned to write another book first, "But God interrupted me and I strongly sensed that I was to do this book on spiritual mapping next because God wanted church leaders to have a practical guidebook for implementing what the Spirit is saying to the churches about spiritual mapping now." "92 Larry Lea, founder of the Church on the Rock (Rockwall, Texas) and author of The Weapons of Your Warfare, also claims a very specific divine calling: "God called me several

86 I return to the lack of questioning and the role of faith below.

87 Cf. Reid, Strategic Level p. 113 regarding Wagner's hermeneutics: "Experience is elevated to a position of high authority when it is confirmed by consensus opinion and apparently positive results; accordingly it may supplant biblical truth."

88 Prince, They shall expel, 9, 44-49.

89 Sumrall, Demons, 9-27.

90 Kraft, Defeating, 5, 13.

91 Wagner, Spiritual Warfare Strategy p. 21.

92 Wagner, Breaking Spiritual Strongholds p. 19. 
years ago to raise up three hundred thousand men and women who would pray daily and intercede for America." 93 Experiencing a divine call to ministry is nothing unique, but these calls are surprisingly specific and grandiose. Wagner was not only called to spiritual warfare; he was a leading figure in the new apostolic movement that taught that in the end times the Holy Spirit would once again anoint apostles. ${ }^{94}$ He in fact considered himself an apostle. ${ }^{95}$ Apostles are highest in the earthly hierarchy of the church according to Wagner; ${ }^{96}$ readers are led to believe that they are in no position to criticize them. Wagner suggests that most people do not have as exciting callings:

God does not call everyone to frontline spiritual warfare any more than he calls everyone to be a public evangelist or a cross-cultural missionary. [... ] Only a tiny percentage of those in the Air Force actually fly the warplanes or even ride in them as crew members. The same applies to spiritual warfare. ${ }^{97}$

The authors of SLSW tradition often claim to have received information directly from the Holy Spirit; Wagner refers to such messages as rhema words, as distinct from the logos words of Scripture. ${ }^{98}$ Thus, Frank Hammond explains that God revealed to them the identity of the 'prince demon' that the devil had assigned over his church: "The prince spirit over the community which I pastored was revealed through a vision from God. The vision revealed a large, octopus-like creature hovering over the community. Across its head was written 'Jealousy'." 99 Wagner claims that there are spiritual powers that govern individual cities and states. He refers to Rita Cabezas, who has a Christian psychology and deliverance ministry, and has learned in part through words of knowledge the names of various members of the demonic hierarchies. Wagner summarizes her findings thus:

She has discovered that directly under satan are six worldwide principalities, named (allowing that this was done in Spanish)... Damian, Asmodeo, Menguelesh, Aris, Beelzebub and Nosferatus. Under each, she reports, are six governors over each nation. ... Those over the US are Ralphes, Anoritho, Manchester, Apolion, Deviltook and one who is unnamed. ${ }^{100}$

How did she come to know this? Wagner explains,

Rita Cabezas has done considerable research on the names of the highest levels of the hierarchy of satan. At this point I will not describe her research methodology, except to mention that the beginning stages were associated with her extensive psychological/deliverance practice and that it later evolved into receiving revelatory words of knowledge. ${ }^{101}$

Among Pentecostals and Charismatics it is widely accepted that people may receive words of knowledge; it is one of the spiritual gifts mentioned by Paul (1 Cor. 12.8). The discernment

93 L. Lea. "Binding the Strongman" in C.P. Wagner (ed.), Territorial Spirits, (2012) p. 111.

94 B.G. McNair Scott, Apostles Today: Making Sense of Contemporary Charismatic Apostolates: A Historical and Theological Approach. (Eugene, OR: Pickwick, 2014).

95 Wagner is designated "Ambassadorial Apostle" on the back cover of Breaking Spiritual Strongholds.

96 Wagner, Breaking Spiritual Strongholds p. 14.

97 Wagner, Breaking Spiritual Strongholds p. 27.

98 Wagner, Spiritual Warfare Strategy pp. 50-53. As Holvast, Spiritual Mapping p. 181, shows, this distinction has no support in the New Testament Greek texts.

99 Hammond \& Hammond, Pigs in the Parlor pp. 26, 28.

100 Wagner, Supernatural Forces p. 85.

101 Wagner, Supernatural Forces p. 85. 
of spirits (1 Cor. 12.10) is also a spiritual gift that spiritual warfare authors refer to. ${ }^{102}$ Wagner has good reasons to believe that his readers would not reject Cabezas's claims off hand.

It is perhaps more problematic that the Holy Spirit is not the only supernatural source of knowledge for those engaged in spiritual warfare. In Defeating Dark Angels, Kraft includes a chapter on "Getting information from demons", ${ }^{103}$ and in his dictionary article "Spiritual Warfare: A Neocharismatic Perspective" he uses a demon as a source. ${ }^{104}$ This practice is supported by reference to Christ's asking the unclean spirit was his name was, and receiving the response "Legion" (Mark 5.9). Wagner offers the following reason for thinking demons may have worthwhile things to say: "Demons are portrayed in the Bible as beings who have personalities and intelligence, and as beings who can and do speak. They are also portrayed as deceivers. It must therefore be concluded that they do possess some valid information." 105 Arnold relates that he knew a minister who used to interview the various demons he cast out of people to determine their hierarchies. He gave up that practice when he discovered that demons lie. ${ }^{106}$ Prince relates that in the 1970's some ministers interviewed demons; "in the end this proved disastrous. The group went into serious doctrinal error and some of them died prematurely." ${ }^{107}$ Murphy however writes how after he exposed a weak demon named Fear, "I forced him to expose the entire demonic hierarchy working in the woman and in her entire family. I have learned how to keep demons from lying to me, so the 'demon's 'finking' on the other demons was later checked out and proved to be truthful." "108 Thus, SLSW practitioners in some cases identified various demonic hierarchies and territorial demons on the basis of demonic testimonies. This practice among SLSW authors of building up a worldview on the basis of information they claim to have received from demons has striking similarities with Modern Esoteric authors who claim to channel various spirits or "ascended masters". ${ }^{109}$ Those who have not made personal context with these celestial beings cannot verify their claims.

\section{"Democratization of privileged experience"}

Authors in the SLSW tradition are not unique in claiming privileged access to spiritual information. It is something they have in common with prophets in various religious traditions, and also with Modern Esoteric authors. ${ }^{110}$ How are readers to determine whether the spiritual warfare authors are really called by God, whether they have really received words of knowledge, or have accurately discerned the spirits?

102 Wagner, Spiritual Warfare Strategy p. 66; K. Warrington, Pentecostal Theology: A Theology of Encounter. (London: T\&T Clark, 2008), pp. 78-79.

103 Kraft, Dark Angels p. 175.

104 "A demon once responded to a question about reincarnation, 'We know people's lives in detail. It's easy for us to simply tell people someone else's life as if it was their own past life."” (C. Kraft, "Spiritual Warfare: A Neocharismatic Perspective" NIDPCM, 2002, p. 1096).

105 Wagner, Spiritual Warfare Strategy p. 67.

106 Arnold, Three Crucial Questions, p. 130.

107 Prince, They Shall Expel, 249

108 Murphy, Handbook p. 53.

109 Hammer, Claiming Knowledge, pp. 379-393.

110 Hammer, Claiming Knowledge pp. 372-3. I have taken the heading "Democratization of Privileged Experience" from Hammer p. 415. 
SLSW authors claim that their interpretation of Scripture yields practices that actually work and deliver people from oppression. ${ }^{111}$ Their experiences in mission field are nothing the reader can verify, but they encourage their readers to try out these practices and see whether their interpretations hold. Wagner argues that spiritual warfare as he presents it should be seen as "at the least, a working hypothesis that we can field test, evaluate, modify, and refine." 112 The readers can simply try spiritual warfare practices themselves to see whether they work. Spiritual mapping clearly requires neither the same amount of education nor the same amount of work as historical and ethnographic research as practiced by academicians. It is quicker and easier to ask a minister to deliver you from demons than to change your life style. This kind of teaching is familiar to many readers, as the notion that quick fixes for spiritual problems are readily available is part of the charismatic heritage. ${ }^{113}$

While SLSW authors encourage their readers to expect spiritual experiences, they also emphasize how many such experiences they themselves have had, thereby setting themselves apart from their readers. ${ }^{114}$ Kraft quotes approvingly his colleague in spiritual warfare Fred Dickason:

I have encountered from 1974 to 1987 at least 400 cases of those who were genuine Christians who were also demonized... I would not claim infallible judgment, but I know the marks of a Christian and the marks of a demonized person. I might have been wrong in a case or so, but I cannot conceive that I would be wrong in more than 400 cases. ${ }^{115}$

Kraft himself writes about "having worked with the Holy Spirit to bring deliverance to more than 2,000 Christians - and dealing with many thousands of demons in the process." ${ }^{116} \mathrm{He}$ mentions how demons acknowledged the authority he had: "As a demon recently said to me, 'Ooh, I'm in trouble now!' Another remarked, 'You really know what you are doing.",117 These authors present themselves as "heroes of the faith", tying into a narrative type common in devotional literature. ${ }^{118}$

Some authors also make sure that readers not have too high expectations. Although every reader can get better at spiritual warfare, they cannot count on having as exciting adventures as the spiritual warfare experts. Wagner writes, "It is only natural, while reading a book like this, to say, 'I want to be like Harold Caballeros' or 'I want to be like Bob Beckett.' Nothing is wrong with desiring to do the things they do, so long as God has called you to do it.",119 One thing the average reader is encouraged to do is elementary historical research. Wagner lets Mark McGregor, a layman who is not a member of the Spiritual Warfare Network, try out his method of spiritual mapping and write up the results in Breaking Spiritual

111 "The theories I like the best are, frankly, the ones that work" (Wagner, Spiritual Warfare Strategy p. 46).

112 Wagner, Strategy, 86.

113 Arnold, Three Crucial Questions p. 133, criticizes deliverance ministries that emphasize "immediate cures". 114 Compare Derek Prince, They Shall Expel Demons, part 2 "In the school of experience", encompasses chapters 4-10. Derek Prince's six tape series "Deliverance and Demonology" (1971) begins with "How I came to grip with demons" and includes his "personal testimony'. Only after that does he examine Gospel texts. file:///C:/Users/hloto/Downloads/Deliverance_\&_Demonology_DD1ol.pdf

115 Kraft, Dark Angels p. 68.

116 Kraft, Dark Angels p. 13.

117 Kraft, Dark Angels p.41.

118 Holvast, Spiritual Mapping p. 178.

119 Wagner, Breaking Spiritual Strongholds p. 27. 
Strongholds to show the reader, "if he can do it, so can you." 120 The dramatic interpretation of the layman's results is then left up to a professional belonging to the Spiritual Warfare Network.

Exorcism isn't always as difficult as it might seem to the uninitiated. Contrary to traditional Pentecostal belief, several spiritual warfare authors teach that everyone can be under the influence of demons and in need of deliverance. ${ }^{121}$ Hammond \& Hammond write, "The emphasis in this book is upon personal deliverance. ... Does everyone need deliverance? Personally, I have not found any exceptions." 122 The second title of their book is "The Practical Guide to Deliverance", and it does offer very concrete advice on how to go about setting people free from demons. ${ }^{123}$ Hammond claims that spiritual warfare is something that concerns all Christians: "demons are spiritual enemies and it is the responsibility of each Christian to deal with them directly in spiritual warfare." 124 But if everyone is in need of deliverance, the experience of actually being delivered is in most cases not likely not to be all that dramatic as those involving the Hammonds. We find a similar approach in Modern Esoteric do-it-yourself practices that amount to little more than a spiritualized redefinition of mundane experiences. ${ }^{125}$

The attitude toward experience shown by the SLSW authors is close to that of New Age authors that they warn their readers about. Like deliverance authors, New Age authors similarly put great emphasis on experience. Hammer writes, "Esoteric movement texts include (and are at times largely constituted by)... narratives of experience, as well as descriptions of rituals that the reader is encouraged to perform in order to gain such experiences." ${ }^{126}$ Both New Age authors and Spiritual Warfare authors present their own experiences as unproblematic source material. But as Hammer notes, "experience itself is permanently beyond the reach of scientific investigation. Nobody can have any access to the experiences of another person, since we cannot see the world from the perspective of anybody but ourselves." ${ }^{27}$ The fact that our memories are not photographs of the past but are actively reconstructed is also something both groups of authors ignore. ${ }^{128}$

\section{Lack of questioning}

The authors refer to their experiences in casting out demons to give them authority. But several are curiously careless in following up on their deliverances. Ida Mae Hammond, who together with her husband helped inspire the SLSW movement, tells of Mary, a six-year-old girl who had been described as being "very stubborn, self-willed and rebellious", whom she delivered of various demons, including demons of fear, of hate, of murder, self-will, mental illness, and insanity. Ida Mae notes that Mary's father said regarding the deliverance session

120 Wagner, Breaking Spiritual Strongholds p. 22.

121 Kraft, Defeating Dark Angels, pp. 36-38; Prince, They Shall Expel, pp 142-154; Sumrall, Demons, pp. $115-$ 123. The Assemblies of God reject this teaching in an official position paper.

122 Hammond \& Hammond, Pigs in the Parlor p. 22.

123 Sumrall, Demons p. 148: "Dominion is for you..."

124 Hammond \& Hammond, Pigs in the Parlor p. 13.

125 Hammer, Claiming Knowledge p. 486.

126 Hammer, Claiming Knowledge pp. 331-332.

127 Hammer, Claiming Knowledge p. 348.

128 Hammer, Claiming Knowledge, p. 348. 
that he "thought that the real Mary was treated rather roughly and said that it was all he can do to keep from interfering." 129 Ida Mae ends her success story, "Though I have not personally seen Mary since her deliverance I have received several good reports. Most say, 'She's so different. 'She just isn't the same.' 'I can hold her and she responds to love.' You just wouldn't believe she is the same girl."

Wagner's coworker Greenwood recounts how she helped a mother of three avoid divorce. "Over the next three months I prayed for her and her husband. Not only did I ask the Lord to restore their marriage, but I warred over their marriage and began to break every scheme and curse the enemy had placed on this couple." Greenwood reports that her efforts were successful. She concludes, however,

We moved to Colorado several months after this occurred, but I firmly believe that she and her family are on the right track and that God will be faithful to bring each of them to the saving knowledge of Jesus Christ. ${ }^{131}$

Firm belief is good, but if she is going to include this as a success story in her book, one might have expected her to do a follow-up. Greenwood's stance is typical of the authors and their target audience. They encourage faith, faith in scripture, but also faith in fellow Christians. Thus, Wagner characterizes his sources as "sincere, lucid people" and chooses not to question their accounts. ${ }^{132} \mathrm{He}$ explains, "we validate the authenticity of reported narratives on the basis of the credibility of those who observe them or experience them." 133 In accepting others' claims at face value, the authors are modelling for the readers how they should receive these texts, and show the attitude they should have in their own deliverance ministries: Don't doubt the efficacy of what you're doing, just believe.

\section{Concluding reflections}

The SLSW authors studied here seek to establish their authority in various ways: by seeming to ground their views in scripture, the ultimate authority in the eyes of Evangelical readers, by establishing themselves as experts in their fields by appealing both to academic credentials and their own success stories, by referring to those who agree with them and ignoring any dissenting voices, and by encouraging an attitude of faith and discouraging questioning. I have showed that there is considerable overlap between these strategies used by authors in the SLSW tradition and discursive strategies identified by Hammer in Modern Esoteric tradition, namely the construction of tradition, scientism and the appeal to experience. These similarities are perhaps not unexpected; both Modern Esoteric authors and the spiritual warfare authors studied here belonged to the same larger cultural context, one colored by American post-Enlightenment values. It is worth noting that SLSW authors have been criticized by Christian theologians for primarily characterizing the western world in terms of enlightenment rationalism, and neglecting the extent to which it was colored by other

129 Hammond \& Hammond, Pigs in the Parlor p. 84.

130 Idem.

131 Greenwood, Authority to Tread p. 23.

132 Quoted in Holvast, Spiritual Mapping, p. 263.

133 Wagner, Spiritual Warfare Strategy p. 57. 
tendencies, such as "mystical romanticism" and "new age' spiritualities." 134 While they warn their readers of the dangers of New Age ideas, and while they on occasion note that they handle similar subject matter as New Age literature, they appear unaware of how much their own attempts at establishing authority had in common with those of New Age authors.

\section{Bibliography}

Anderson, Allan (2004), An Introduction to pentecostalism: Global charismatic Christianity. Cambridge: Cambridge University Press.

Arnold, Clinton E. (1989), The concept of power in Ephesians. Grand Rapids: Baker Book House.

Arnold, Clinton E. (1996), The Colossian syncretism: The interface between Christianity and folk belief at Colossae, Grand Rapids: Baker Books.

Arnold, Clinton E. (1997), Three crucial questions about spiritual warfare. Grand Rapids. Baker.

Beckett, Bob ([1993] 2015), "Practical steps toward community deliverance" in C.P. Wagner (ed.), Breaking spiritual strongholds in your city: 141-162.

Beilby, James K. \& Paul Rhodes Eddy (eds.) (2012), Understanding spiritual warfare: Four views. Grand Rapids: Baker Academic.

Boyd, Gregory A. (1997), God at war: The Bible and spiritual conflict. Downers Grove: InterVarsity Press.

Brown, Derek R. (2011), "The Devil in the details: A survey of research on Satan in Biblical studies," Currents in Biblical Research 9.200-227.

Bultmann, Rudolf (1961), "New Testament and mythology" in R. Bultmann, et als., Kerygma and myth: A theological debate. New York: Harper \& Row.

Caballeros, Harold ([1993] 2015), "Defeating the enemy with the help of spiritual mapping" in C.P. Wagner (ed.), Breaking spiritual strongholds in your city,: 119-140.

Collins, James M. (2009), Exorcism and deliverance ministry in the twentieth century: An analysis of the practice and theology of exorcism in modern Western Christianity. Paternoster.

Collins, John J. (1993), Daniel. Minneapolis: Fortress Press.

Davies, Stevan L. (1995), Jesus the healer: Possession, trance and the origins of Christianity. London: SCM Press.

Dickason, C. Fred. (1995), Angels: elect and evil. Chicago: Moody Publishers.

Dorrien, Gary (1998), The remaking of evangelical theology, Louisville, KY: Westminster John Knox.

Garrard-Burnett, Virginia (2009), "Casting out demons in Almolonga: Spiritual warfare and economic development in a Maya town," in Westerlund, David (ed.), Global Pentecostalism: Encounters with other religious traditions. London: I.B. Tauris: 209225.

Greenwood, Rebecca (2005), Authority to tread: An intercessor's guide to strategic-level spiritual warfare. Grand Rapids: Chosen Books.

Guntrip, E. D. (2006), A Pentecostal study of Daniel's Prince of Persia (Daniel 10:13) (Doctoral thesis, Australian Catholic University).

Hammer, Olav (2004), Claiming knowledge: Strategies of epistemology from theosophy to the New Age. Leiden: Brill.

134 Priest, Campbell \& Mullen, “Missiological Syncretism: The New Animistic Paradigm” 1995 p.11, also quoted in Holvast, Spiritual Mapping, p. 266. 
Hammond, Frank (1994), The saints at War: Spiritual warfare over territories. Kirkwood, MO: Impact Christian Books.

Hammond, Frank and Ida Mae (1973), Pigs in the parlor: The practical guide to deliverance. Kirkwood, MO: Impact Christian Books.

Hanegraaff, Wouter J. (1998), New Age religion and Western Culture: Esotericism in the mirror of secular thought. Albany, NY: State University of New York Press.

Hanegraaff, Wouter (2005). "Esotericism" in Hanegraaff, (ed.), Dictionary of gnosis and Western esotericism. Leiden: Brill, pp 336-340.

Hart, John (1997), "The Gospel and spiritual warfare." Journal of the Grace Theological Society 10: 19-39

Holvast, René (2009), Spiritual mapping in the United States and Argentina, 1989-2005: A geography of fear. Leiden: Brill.

Jacobs, Cindy ([1993] 2015), "Dealing with strongholds" in C.P. Wagner (ed.), Breaking spiritual strongholds in your city: 73-93.

Jorgensen, Dan (2005), "Third wave evangelism and the politics of the global in Papua New Guinea: Spiritual warfare and the recreation of place in Telefolmin," Oceania 75: 444461.

Kraft, Charles H. ([1992] 2011), Defeating dark angels: Breaking demonic oppression in the believer's life. Ventura, CA: Regal Books,.

Kraft, Charles. (2002), "Spiritual warfare: A neocharismatic perspective" NIDPCM: 10911096.

Lea, Larry (2012), "Binding the strongman" in CP Wagner (ed.), Territorial spirits: 107- 120.

Lorenzo, Victor ([1993] 2015): "Evangelizing a city dedicated to darkness" in C.P. Wagner (ed.), Breaking spiritual strongholds in your city: 163-183.

Lowe, Chuck (2001), Territorial Spirits and World Evangelisation: A Biblical, Historical and Missiological Critique of Strategic-Level Spiritual Warfare. Christian Focus Publications.

McCloud, Sean (2015), American possessions: Fighting demons in the contemporary United States. Oxford: Oxford University Press.

McNair Scott, Benjamin G. (2014), Apostles today: Making sense of contemporary charismatic apostolates: A historical and theological approach. Eugene, OR: Pickwick.

Meadowcroft, Tim (2004), "Who are the Princes of Persia and Greece (Daniel 10)? Pointers towards the Danielic vision of earth and heaven." JSOT 29: 99-113.

Murphy, Ed (2003), The handbook for spiritual warfare. Revised and updated. Nashville: Thomas Nelson.

Otis, George, Jr. (2015), “An overview of spiritual mapping” in C.P. Wagner (ed.), Breaking spiritual strongholds: 33-50.

Powlison, David (1995). Power encounters: Reclaiming spiritual warfare. Grand Rapids: Baker Books.

Powlison, David (2012), “The classical model.” In Beilby \& Eddy (eds.), Understanding spiritual warfare: $89-111$.

Priest, Robert J., Thomas Campbell \& Bradford A. Mullen (1995), "Missiological syncretism: The new animistic paradigm" In E. Rommen, ed., Spiritual power and missions: Raising the issues. Pasadena: Carey Library: 9-87.

Prince, Derek (1998), They shall expel demons: What you need to know about demons - your invisible enemies. Grand Rapids: Chosen.

Reid, Michael S.B. (2002), Strategic level spiritual warfare: A modern mythology? A detailed evaluation of the biblical theological and historical bases of spiritual warfare in contemporary thought. Fairfax, VA: Xulon Press. 
Smith, Graham R. (2016), The church militant: Spiritual warfare in the Anglican charismatic revival. Eugene, OR: Wipf \& Stock.

Stambach, Amy (2009), "Spiritual warfare 101: Preparing the student for Christian battle," Journal of Religion in Africa 39: 137-157.

Stevens, David E. (2000), "Daniel 10 and the notion of territorial spirits" Bibliotheca Sacra 157. 410-431.

Sumrall, Lester (2003), Demons: The answer book. New Kensington, PA: Whitaker House.

Twelftree, Graham H. (1993), Jesus the exorcist. WUNT 54. Tübingen: Mohr Siebeck

Twelftree, Graham H. (2007), In the name of Jesus: Exorcism among early Christians. Grand Rapids: Baker Academic.

Wagner, C. Peter (ed.) ([1993] 2015), Breaking spiritual strongholds in your city. Shippenburg, PA: Destiny Image.

Wagner, C. Peter (2011), Spiritual warfare strategy, Shippensburg, PA: Destiny Image. [originally published as Confronting the powers, 1996]

Wagner, C. Peter (ed.) (2012), Supernatural forces in spiritual warfare: Wrestling with dark angels. Shippensburg, PA: Destiny Image.

Wagner, C. Peter (ed.) (2012). Territorial spirits: Practical strategies for how to crush the enemy through spiritual warfare. Shippensburg, PA: Destiny Image.

Wagner, C. Peter \& Rebecca Greenwood (2012), "The strategic-level deliverance model." In Beilby \& Eddy (eds.), Understanding spiritual warfare: 173-198.

Warrington, Keith (2008), Pentecostal theology: A Theology of encounter. London: T\&T Clark.

Witmer, Amanda (2012), Jesus, the Galilean exorcist: His exorcisms in social and political context. London: T\&T Clark. 